\title{
Russian Influence in the Czech Republic as a Grey Zone Case Study
}

\author{
JOSEP BAQUÉS-QUESADA AND GUILLEM COLOM-PIELLA
}

\section{sciendo}

Politics in Central Europe (ISSN: 1801-3422)

Vol. 17, No. 1

DOI: 10.2478/pce-2021-0002

\begin{abstract}
In recent years, the concept of grey zone has been popularised to analyse the activities a State can use to influence the decisions and to limit the strategic choices of another State below the threshold of war. This article presents a case study, aimed at verifying if the Russian activities in the Czech Republic may constitute a grey zone. The paper commences by introducing the concept of the grey zone and developing the appropriate theoretical framework to identify its main characteristics. It continues by examining the Russian influence in the Czech Republic by using open sources, local sources and documents from the Czech intelligence services. It concludes by asserting that the analysed case meets most of the requirements to classify it as a 'limited grey zone'. This new theoretical development may help to assess similar situations that may occur in this or other nations.
\end{abstract}

Keywords: grey zone; hybrid threat; Russia; Czech Republic; political influence; disinformation; active measures.

\section{Introduction}

A number of buzzwords - from the traditional ideas of 'disinformation' and 'active measures', the catch-all concept of 'hybrid threat', the inexistent 'Gerasimov doctrine' or the ambiguous 'grey zone' - are used to define Russia's political warfare activities in the West. ${ }^{1}$ Among others, those can include political in-

1 More specifically, those may be tactics of the Russian approach to unconventional warfare. Dubbed by a number of experts as New Generation Warfare, it '...differs from Western views of hybrid warfare a blend of conventional, irregular and cyber warfare [the current hybrid threat approach focuses on the multidimensional strategies (or traditional political warfare activities) below the threshold of war] - in 
terference, information operations, economic pressure, criminal activities or show of force. This article aims to set out a series of research findings on such activities in Eastern European countries, using the Czech Republic as a case study to apply the grey zone (GZ) theory. The research question is whether the Russian actions in the Czech Republic may constitute a GZ.

This proposal is, theoretically speaking, mature. In fact, before the grey and not so grey - activities in Ukraine that led to redefining and popularising the original concept of a hybrid threat, some experts pointed out that Russia might exert pressure in some former Warsaw Pact countries as a means to erode NATO (Trenin 2011: 107). More recently, organisations such as NATO and the EU pointed out the convenience of monitoring the Russian activities in various European States, since there were signs of high proactivity which could not be the result of chance (Morris 2019).

To transform the research question into a hypothesis, we analyse whether Russia is taking advantage of its historical ties, political relationships and commercial contacts in the Czech Republic to generate a GZ in the country. Our hypothesis is that Russia is developing a GZ in the Czech Republic. The $\mathrm{GZ}$ tactics, techniques and procedures used by Moscow may have three main goals in the Czech Republic: influence the country's domestic decisions, detach it from the EU and NATO, and erode both organisations.

To carry out this research, the first section of the article develops a theoretical framework of the GZ and outlines the objectives that can be pursued through this strategy, as well as the means used for it. The second section describes the case-study method used in this research. The third section examines the relations between Russia and the Czech Republic to underline some of the basic assumptions of the clash of narratives, which always constitute the substrate of a GZ. Fourth, the connections and practical outcomes between some top Czech leaders and the Kremlin are analysed. Fifth, a number of Russian interferences including economic and diplomatic pressures - in the Czech Republic are analysed. The article concludes by testing the hypothesis and making a theoretical contribution that may be useful for other case studies.

\section{Grey Zone as a theoretical framework}

A GZ can be defined as the strip that separates peace from war and which has been turned into an ambiguous new battlefield. It is precisely this ambiguity that allows actors to project their power knowing that, if their activities cannot easily be traced back to them, can be plausibly denied, and do not affect the

that it combines low end hidden state involvement with high-end direct, even braggadocio, superpower involvement' (Karber - Thibeault 2016). Debates on the 'Russian new wars' can be found at Gareev (1998), Berzins (2015, 2014), Galeotti (2016) and, above all, the works by Timothy Thomas (2016). 
vital interests of their victims, it will be difficult to deploy a clear and effective response by the defenders of the status quo ante.

Taken in isolation, these actions that may include support for political opposition, economic coercion, influence activities, cyberattacks, aggressive intelligence, coercive deterrence or fait accompli policies would hardly constitute a casus belli because they will seek to remain below the threshold of conflict. However, their aggregate long-term effect by using 'salami tactics' (Haddick 2012) - combining actions that provide small gains - may alter existing correlations of forces. The GZ is the natural battleground for traditional political warfare activities, which employ all the instruments at the disposal of a State to weaken, influence and demoralise their adversary politically, militarily, economically or socially (Robinson 2018; Polyakova - Boyer 2018).

These multidimensional strategies have become popularised as hybrid threats. ${ }^{2}$ In fact, a GZ may constitute its less kinetic version, as opposed to 'classical' hybrid warfare theories, in which an armed conflict does occur (Hoffman 2012).

In this regard, despite the theoretical, historical and practical limitations of such concepts (Stroker - Whiteside 2020; Echevarria, 2016), there is broad doctrinal consensus on their practicality to describe a wide range of activities to project influence under the threshold of armed conflict, which forms the basis of this research (Chambers 2016; Koven 2016; Freier 2016; Mazarr 2015; Hoffman 2015; Brands 2016; Votel et al., 2016; Baqués 2017; Jordán 2018; Colom, 2019).

The situation in a GZ is one of warring peace, contrary to the principles of bona fides destined to govern International Relations, to the point of being a tertium genus between situations of genuine (Kantian) peace and war (Schadlow 2014; Brands 2016). Basically, although a GZ may be minimalist in the means employed, it is maximalist in its aims, which are similar to those that would have required the outbreak of a war in the past.

Thus, the concept of a GZ enhances analysis of actions taken by major powers in the context of what some refer to - with evident Clausewitzian traces ${ }^{3}-$ as the 'fog of peace' (Goldman 2011) on account of its ambiguity. It is a reasonable instrument in the hands of a state which, although powerful, is not yet powerful enough to impose a military solution on the powers interested in defending the status quo.

2 It is important to bear in mind that this concept had its origins in the idea of complex-irregular warfare, but it was the war of 2006 between Hezbollah and Israel that led to its development. In this sense, it was originally coined to define '.... a range of different modes of warfare, including conventional capabilities, irregular tactics and formations, terrorist acts including indiscriminate violence and coercion, and criminal disorder' (Hoffman 2007: 14).

3 The Prussian used to refer to the 'fog of war' to warn about situations that were not predictable in the plans of military leaders, but which affected their conduct. In the context of the GZ, this concept is very useful for alluding to similar situations, but in times of peace. 
To gain a better understanding of the GZ, we should analyse its ends, ways and the means used to achieve them. In fact, they are relevant to the extent that a truly operational concept of the GZ can be built from them.

The work carried out throughout our research, reflected in this article, has been developed using them as a framework. The inspiration for its contents has been developed from previous works in which this framework has been outlined (Mazarr 2015; Baqués 2017; Jordán 2018). In this way, it is possible to draw up a package of the ends for a GZ, as well as another aimed at setting out the means used to achieve them.

a) A GZ is a particularly suitable resource for moderately revisionist powers. These are states that question the role of other powers, even the major powers, but are not so uncomfortable with the status quo to initiate a war. Their actions are, therefore, based on a certain strategic patience or gradualism (Mazarr 2015: 58-60). This is one of the reasons why they develop such zones as a pressure strategy: the GZ increases its effectiveness in the medium and long-term, although in the short-term is debatable.

b) This revisionism is maximalist in its objectives (Brands 2016). In fact, it is intended to achieve warlike aims. The novelty lies, therefore, in the instruments used for this purpose. According to the dominant doctrine (Mazzar 2015: 91; Freier 2016: 33; Echeverría 2016: 13; Votel 2016: 107), they can range from supporting domestic movements, forcing changes of government or influencing its political leadership when this has geopolitical implications, to even annexing part of another state.

c) Because of (a) and (b), the promoters of a GZ want to avoid a casus belli. Thus, those who would seek to promote a GZ do not cross the red lines that would justify an armed response from the defenders of the status quo ${ }^{4}$. The key is that these actions must not be (openly) against International Law. If necessary, they will develop in the slippery area of lawfare (Echeverria 2016: 38). According to Chambers (2016: 27) the key to the success of a GZ lies in the ambiguity and non-attribution of the actions taken.

d) In accordance with points (a) and (b), a GZ is a way of exerting pressure without military escalation. However, in the event of armed confrontation, those who have taken greater advantage of the $\mathrm{GZ}$ are more likely to win. For this reason, a GZ can be the prelude to a war. ${ }^{5}$ In other words, a GZ can

4 In this sense, maybe the conventional military balance between the competing parties is an important aspect for assessing the success of a grey zone. If the actor developing a grey zone also maintains military superiority, it will likely maintain the scalation dominance in any scenario. This possibility might have important practical effects, since it could help to understand and establish relationships between the consolidation of Anti-Access/Area-Denial (A2/AD) capabilities with the increase of the GZ activities.

5 An account of the problems related to deterrence in a GZ can be found in Matisek (2017). However, the elimination of Iranian general Qasem Soleimani with no escalatory effects (at least so far) seem to demonstrate that an actor cannot only restore deterrence by climbing a step in the escalation ladder (Byman, 2020), but also restore the strategic initiative and make a GZ disappear, at least temporarily. 
be an alternative to war, but it can also be a preparation for it (Mazarr 2015: 58; Chambers 2016: 30-31).

The means are also important for defining a GZ. If some are identified in a particular scenario, a connection to the ends already exposed through a bottom-up approach may be made. In this sense, although there are many shades of grey on the spectrum from white (peace) to black (war), the following can be considered key features ${ }^{6}$ :

e) The basis of a GZ is a narrative that influences society as a whole and erodes the credibility of status quo advocates. It may take place both within and beyond the geographical borders of the $\mathrm{GZ}$ to erode the international legitimacy of status quo advocates (Freier 2016: 39-40). It is also useful to have the necessary channels to disseminate it - especially mainstream media and social media - to achieve the desired effects. ${ }^{7}$ This narrative also entails the use of propaganda, disinformation and deception (Mazarr 2015: 109-110).

f) Civilians are placed front and centre in a GZ. This is important when it comes to fulfilling the provisions of point (c) concerning the purposes of the GZ: not to generate a casus belli. They are on the receiving end of influence and information operations, but they are also the agents of such operations, acting as collaborators, informants, broadcasters or funders of such initiatives (Votel 2016: 40).

g) The GZ incorporates measures that place economic pressure (Freier 2016: 41) on those who defend the status quo, weakening their position and discouraging their policies in terms of rational calculation. Such measures are usually legal (subsidies and boycotts), although on occasion they conceal blackmail (total or partial cut-off of supplies or the threat to do so).

h) The proponent of a GZ requires military support/deterrent to avoid the response from those who would defend the status quo, even at the cost of

6 Many of the GZ activities can be carried out in the physical world (from the traditional incursions of Chinese fishermen into the disputed islands with Japan to the attacks on Saudi tankers in the Persian Gulf). However, the popularisation of the GZ theories - as well as the current debates on hybrid threats is related to the activities performed in the virtual domain. This is due to the ambiguity, anonymity, asymmetry, economy and ubiquity that characterise the information sphere. These features allow many actors to project their power asymmetrically by hindering the attribution of their actions, preventing the allocation of legal responsibilities, hampering any retaliation and compromising credibility of the deterrent tools of the victim.

7 The use of disinformation, misinformation and propaganda to influence allied, neutral or adversary, and domestic as well as foreign populations is not new. However, a number of factors - from the information revolution, the penetration of internet in the societies, the changing preferences of the population, the crisis of the traditional mass media to the weaponisation of the information domain - have increased its impact. Now, tactics such as multi-channel propaganda, user profiling to reinforce the filter-bubble, dissemination of fake news or leaking compromised personal information could also be used to undermine trust in political institutions, exploit existing divisions in societies and influence public opinions. There is abundant literature on the subject, but Polyakova and Boyer (2018), and Bradshaw and Howard (2018) provide a general account of the situation. 
appearing as aggressors (Baqués 2017: 24-25). ${ }^{8}$ This buys them time so that the actions described in points (e), (f) and (g) can take effect.

\section{Methodology}

On the basis of this theoretical framework, the article will proceed to examine the specific case of the Czech Republic as a potential Russian GZ. This analysis aims to complement the ongoing debates on disinformation and hybrid threats affecting the country, which Mareš, Holzer and Šmíd (2020) and Daniel and Eberle (2018), among others, provide detailed accounts from academia.

The case study is the most appropriate methodology to address this task. On the one hand, by developing a reasonably generous approach to the object of analysis, case studies offer complex answers, with many nuances, to why and how certain phenomena occur (Chetty 1996). On the other hand, case studies allow for observation of the object with greater analytical depth than the use of qualitative methodology because of the variety of sources and perspectives narratives, events, tools or actors - used in approaching it. This allows us to develop a research that is certainly robust on an empirical level.

The other advantage of this approach is that it encourages the possibility of constant feedback on the connections between theory and practice. Indeed, case studies make it easier for the theory, approach or perspective applied (the GZ) to be contrasted with the case study (the Czech Republic). But, even if the immediate objective remains the verification of a hypothesis, this methodology can contribute to the improvement of the theory itself (Stake 1994). Indeed, the GZ are a relatively recent field of study, which may be subject to further refinement.

Therefore, case studies are particularly useful for developing a new theory, or for refining an existing one (Eisenhardt 1989: 545; Merriam 1998). In this case, the variant known as 'gaps and holes' will be used (Yin 2014; Ridder 2017) to stress the bidirectional relationship between the existing theory and the case of study. Precisely, this case study may contribute to the improvement of the theoretical frameworks currently available (in this case, the GZ approaches) so that they can be applied to future cases (Pinfield 1986). This theoretical sensitivity has contributed to the choice of this methodology to develop the research from which this article arises.

As indicated so far, the underlying research question is whether Russia has developed a GZ strategy in the Czech Republic. On the one hand, Russia might be using practically all the means described in the theoretical framework to achieve some of the aims of the GZ, and its attempt to have like-minded governments in Prague to condition the Czech role in the main European institutions

8 This might be the situation that arose when the U.S. intervened in Grenada (October 1983) because of the arrival of Cuban workers. However, the USSR was too weak to adopt forceful measures against Washington. 
is particularly relevant. On the other hand, the nuances point, firstly, to the advisability of not systematically equating the development of a $\mathrm{GZ}$ with its prospective success. This is because the GZ resources, which are important, are still limited compared to those that would be on the agenda in the event of war. Therefore, this case study demonstrates the need for the general GZ theory to be open to Grygiel and Mitchell's (2017: 59-61) hypotheses, according to which these strategies are orchestrated to check possible reactions of rival powers, though always in the spirit of the GZ, that is, without triggering wars. And all this is without prejudice to the parallel interest in damaging the reputation of those affected by the establishment of a GZ.

\section{The Czech Republic case study}

\section{Context and evolution}

Unlike Estonia, Latvia, Lithuania and Poland, the population and territories that make up the present-day Czech Republic hold no major historical grievances with the Russian Federation. For centuries, relations between Russia and the territories that were part of the current Czech Republic (v. gr. Bohemia) were friendly, because the Russian Empire was the last defensive bastion of the Slavic peoples in the face of German or Turkish expansionism (Kratochvil 2004: 1).

Thus, after considering that the West betrayed Czechoslovakia in the Munich Agreements (1938) by endorsing the incorporation of Sudeten Germans into Germany, not only did the outcome of World War II - with the Soviet expulsion of German troops - not pose a problem for most Czechs, it also left a feeling of déjà vu. This situation facilitated the acceptance of the political, economic and social changes that occurred in Czechoslovakia after 1945 ... for a few years at any rate.

The problem - which had lain dormant for years - was rooted in the totalitarian nature of the Soviet regime and its thirst to control the States that it considered satellites. The experience of the Prague Spring (1968), therefore, gave rise to an enduring conceptual shift between the two countries (Benyumov 2018). Russia's image as protector has become one of a State that sparks suspicion and fear among much of the Czech population.

The Russian narrative continues to emphasise the 'liberation' they provided at the end of World War II, skirting around - and even omitting all together any reference to episodes such as Hungary (1956) or Czechoslovakia (1968) (Walker 2018). Moreover, the Czech Republic remains an important and valued trading partner, while the Slavic nature of the Czech people - as well as the fact that Catholicism has barely taken hold there ${ }^{9}$ - helps Russia to maintain this favourable viewpoint, beyond any historical disagreements.

9 Indeed, according to data from the US think tank PEW for 2017, 72\% of the Czech population profess no belief, while 27\% declare themselves to be Catholic and 1\% orthodox (Cooperman 2017: 20). 
Finally, the geographical situation of the Czech Republic is highly valued by Russian criminal networks - along with Ukrainian, Armenian, Uzbek and Chechen networks - to carry on their illegal activities (Security Information Service [BIS] 2004). Since the fall of the Iron Curtain, these networks have used the country as a meeting point or transit route for drug, weapons and human trafficking. However, these criminal networks, which collude to a certain extent with Czech economic, financial and political sectors (Bugajski 2004: 152-60; Wesolowsky 2003: 15) ${ }^{10}$, appear to be collaborating with Russian security operations in terms of intelligence, influence, financing, murder or cyberoperations (Galeotti 2017). ${ }^{11}$ This is relevant to our work, since the use of proxies to project power makes it difficult to attribute actions and contributes to the consolidation of the GZ (Jordán 2018).

Russian foreign policy towards the Czech Republic has undergone several phases since the end of the Cold War: An initial phase (1993-97) of discontent and even pressure, followed by a certain degree of disinterest (1997-99) before culminating, from the year 2000 onwards, in a kind of 'normal relationship' once the irreversibility of Czech integration into Western security structures had been accepted (Holzer et al. 2020: 56-58; Kratochvíl 2004: 2-4). ${ }^{12}$ This helped to defuse some of the accumulated misgivings, since, although at the start of the cold-war Russia was regarded as an enemy by the majority of the Czech population, ${ }^{13}$ it gradually became for many '... a partner in economic and energy matters' (Kratochvil - Kuchyňková 2010: 196). ${ }^{14}$

However, at the end of the last decade, this pragmatism - accompanied by a certain degree of concern in the Czech Republic about the health of Russia's democracy and its respect for human rights - in dealing with bilateral

10 Although the sources underscore this political connivance through action or omission, it is worth noting that Transparency International assigned the country 56 points out of 100 in 2019, making it the $44^{\text {th }}$ least corrupt country in the world. Available on the webpage: https://www.transparency.org/cpi2019 (09 November 2020).

11 Although intelligence reports refer to criminal networks from the former USSR and their links with their countries of origin, it was not until the 2010 report that the Czech security services suggested: 'Contacts of officers of Russian intelligence services with persons whose past is associated with Russian-language organised criminal structures and their activities in the Czech Republic are somewhat disturbing' (BIS 2011: 10). This should not come as any great surprise, since contacts between organised crime and Russian intelligence services were established by the tsarist police in the nineteenth century and maintained during the Soviet era.

12 Czech integration into NATO was one of the main objectives of President Havel's foreign policy, as opposed to maintaining Finland-style neutrality or security relations with Moscow. Although this goal was achieved in 1999, Russia had tried to prevent Czechoslovakia from falling into the allied orbit, including military transfers to modernise its armed forces, something that occurred once again in the 2000s.

13 Indeed, in 2003 - one year before Czech secret services publicly exposed that Russia had begun to engage in influence activities - only 3\% of the country's population was suspicious of their Eastern neighbour (Bugajski 2004: 153).

14 Soon, issues related to the economy, energy, science and industry would become the main targets of Russian espionage from the mid-1990s onwards (BIS 2009: 5). 
relations became more complicated. Firstly, because of the agreement between Washington and Prague to deploy components of the US missile defence shield in Czech territory (Paszewski 2013) ${ }^{15}$. Motivated by Russian misgivings about the real purpose of this system aimed at protecting the US from Iranian and North Korean ballistic missiles, and by its loss of influence in Central and Eastern Europe, this controversy reached a peak between 2007 and 2009, fading away shortly thereafter, once the programme had been cancelled. But Moscow took note of Prague's role as Washington's ally in the region. This explains why Russian grey activities in the Czech Republic seek to generate distrust of the Atlantic Alliance and the European Union, to demonstrate to Russian public opinion that Moscow has allies in the West, and to regain the influence lost after the end of the Cold War (Morris et al. 2019: 63; Waisová 2020). ${ }^{16}$

The second issue was the discovery that the Kremlin had resumed - though it may never have actually ceased - '...the Soviet practice of using active measures to promote its foreign-policy interests' (BIS 2009: 5). As early as the 1990s, Czech information services observed that the number of workers at the Russian embassy in Prague was unusually high and that this could be due to Russia's determination to establish an espionage network in the country. At the same time, they detected activities to '...influence decisions in local governments, spread false information, erode the country's credibility abroad, and undermine citizens' confidence in its authorities' (BIS 1997, quoted in Bugajski 2004: 160). These were in addition to the 'standard' efforts to attract collaborators among extremist groups, police forces, military personnel, local representatives, politicians and businessmen, or political, military, scientific, technical and economic espionage (BIS 2016: 8). However, it was from 2000 onwards - coinciding with Putin's arrival in the Kremlin ${ }^{17}$ - that they detected a surge in these efforts among officials, politicians

15 Washington intended to deploy an X-band radar at a base $150 \mathrm{~km}$ from the Czech capital. The conservative Topolánek government (2006-09) felt that the agreement would improve relations with Washington, strengthen the Czech position in European defence, and facilitate the development of the allied anti-missile system. This decision was criticised by communists and social democrats, conditionally supported by the greens, endorsed by liberals and disapproved of by the majority of citizens. Criticism was levelled against the potential effects of the radar on the environment and health of local residents, the legal status of US troops, the risks of terrorist attacks, and the limited economic or technological compensation. Although the agreement was eventually signed in 2008 , parliamentary ratification was postponed several times until the fall of the Topolánek government and Obama's entry into the White House archived this project definitively. Dodge (2020) offers a comprehensive account of this issue.

16 In 2016, Czech security services stated that Russian information campaigns were pursuing six major objectives: (1) weaken the media (through infiltration and the spread of propaganda and disinformation), (2) strengthen the news resilience of the Russian population (by fabricating information from Czech sources for the Russian audience), (3) influence Czech perceptions and undermine their resilience, (4) promote social tensions (creating proxies or supporting extremist actors), (5) demeaning Czech support for NATO and the EU (undermining Czech-Polish relations, defaming both organisations or spreading rumours of war with Russia) and (6) damaging Ukraine's reputation in order to isolate it internationally (BIS 2016: 9).

17 Bugajski (2004: 160) argues that there is a direct relationship between the arrival of Putin and the rise in the activities of Russian intelligence services. 
(especially former Communist Party members), military personnel, businessmen, and members of the Russian diaspora (BIS 2004: 8) ${ }^{18}$. Although they believed that these movements sought to improve Russian intelligence about Czech politics and the allied defence, and to strengthen Moscow's economic influence ${ }^{19}$, in 2008 they corroborated that Moscow had taken active measures (Aktivmye Meropriyatiya) to influence, disinform and potentially destabilise the country $^{20}$. Not only was Russian intelligence supporting proxies, creating front organisations, and engaging agents of influence among the Czech population, it was also infiltrating internationalist or civic groups with false-flag tactics. They were blackmailing citizens into collaborating and had begun to spread false narratives, amplify socio-political cleavages, and influence the country's political and business decisions (BIS 2009: 5; Waisová 2020). Over time, these activities became more systematic, exploiting cyberspace, communication platforms, and nationalist, populist or anti-immigration movements, seeking social polarisation, political radicalisation, distrust of institutions and subverting the existing constitutional order (BIS 2019: 8-10; Facon 2017; Janda - Víchová 2017).

The final trigger was the start of Vladimir Putin's second presidential term (2012-), which cooled relations between the two countries on account of Russia's growing assertiveness in its area of influence. This culminated in the annexation of Crimea (2014) and military intervention in eastern Ukraine (2014-). Since then, more and more anti-Russian voices have been heard among Czech politicians (Benyumov 2018; Walker 2018). ${ }^{21}$

But Moscow was already implementing its own plan to counter that mood. In the years between the fall of the Czechoslovak Communist regime and $\mathrm{Pu}$ tin's return to power (2012), at least two political parties consistently held pro-Kremlin positions - the Communist Party of Bohemia and Moravia (KSČM) and the Czech Social Democratic Party (ČSSD). Similarly, figures such as Miloš

18 However, the 2008 report states that these activities - focused especially on MPs, political advisers and the business sector - date back to the early 1990s (BIS 2009: 5-6).

19 More specifically, they would seek to strengthen Russian-Czech trade relations, obtain relevant information to win public contracts or support the conclusion of contracts in an illegal manner (BIS 2004: 8). In fact, several sources have linked the country's current president Miloš Zeman to these practices since the early 2000s (Bugajski 2004; Wesolowski 2003).

20 Used extensively during the Cold War, they not only practised disinformation, propaganda, manipulation and the counterfeiting of documentation by means of open, semi-covert or clandestine media, they also used a wide range of proxies (parties, unions, or associations with accredited links to Moscow), front organisations (scientific, cultural or pacifist entities with no apparent relationship with the Kremlin), economic manipulation, blackmail, agents of influence (who would use their position to secretly support Moscow), or collaborators who would consciously or unconsciously support the Soviet narrative (Bittman 1985).

21 This does not mean that the country has neglected its economic pragmatism, as many continue to consider - especially in the aftermath of the most recent financial crisis - that Russia is an important trading partner with which ties should be strengthened in order to reduce Czech dependence on European markets (Jirušek - Kuchyňková - Vlček 2020: 120-21). 
Zeman - President of the country since 2013 - were already showing promise in this direction (Kratochvíl - Kuchyňková 2010: 197).

Indeed, over these years, many pro-Russian Czech politicians have struck a balance in interpreting the most sensitive historical events, avoiding burning bridges with Moscow. According to this interpretation, the Prague Spring would not have been the result of Russian aggression as a nation, but a Soviet-style Communist aggression that has nothing to do with the current Russian Federation (Walker 2018). By disentangling these two variables, the dilemma is removed from the equation, although this cannot be sustained in geopolitical terms.

On the basis of this interpretation of the facts, there is a clash of narratives, beyond the positions defended by its governors, although, logically, these positions also pick up on various sensitivities with regard to Russia. Václav Havel President from 1993 to 2003 - had a good personal relationship with Mikhail Gorbachev, and then Boris Yeltsin, but his preferences - and his interpretation of history - were closer to those of the United States and Western Europe, with all that implies (Walker 2018). Today's leaders, on the other hand, advocate very different positions (Holzer et al. 2020: 79-82).

\section{Russia's strong men in the Czech Republic?}

Miloš Zeman has been President of the Czech Republic since 2013 and was previously Prime Minister (1998-2002). The current Prime Minister Andrej Babiš (2017-) has followed a similar path. Both come from communism and are currently active in populist parties that have gradually moved away from traditional formations (Hanley - Vachudova, 2018). Their biographies are important and contain significant data for our research.

Zeman was a member of the Czechoslovak Communist Party from 1968 to 1970. After a few years without displaying any obvious militancy, he rose up through the ranks of the ČSSD until he eventually left to found a social democratic party in 2009 - the Party of Civic Rights - Zeman's people (SPOZ) founded in his image and likeness.

His messages have been controversial, calling Islam the 'enemy' and 'anti-civilisation' (CTK 2011), statements that extrapolate any legitimate debate about the most appropriate migration policies. In fact, Zeman praises any move the Kremlin makes, either in Crimea, or in Ukraine, denying Russian intervention in the latter case (Ereli 2017). Zeman says that there is simply a 'civil war' in Ukraine (Špalková - Janda, 2018: 2). But this 'simply' - ignoring Moscow's support for the Donbass separatists and its participation in hostilities - clearly underscores the problem raised in his speech ${ }^{22}$.

22 If he views the conflict in Ukraine as a civil war, Zeman cannot defend Russian intervention, because in this type of conflict foreign intervention is only legitimate when it seeks to counter previous actions by States that support the other side. 
These facts could be due to his Communist past, to the consideration of Russia as the last bastion of the West, or due to his own sympathies towards Putin. However, there are other factors that explain Zeman's ties to Moscow. We cannot rule out the possibility that, as a former member of the Czechoslovak Communist Party, he was co-opted by Russian intelligence in the 1990s. Furthermore, Zeman was involved in several corruption scandals when he was Prime Minister (1998-2002). Cases such as the unjust awarding procedure for the contract to build the D-47 highway, or the appointment of the Falkon Capital financial group to manage debts owing to Russia (Bugajski 2004: 156-57) link him with organisations that maintain ties with the Kremlin and probable relationships with organised crime.

He is notoriously a friend to Russian tycoons, including former diplomat Vladimir Yakunin, former director of Russian railways, which currently sponsors the Rhodes Forum, one of the most active organisations in the struggle between the Kremlin and Western institutions (Morris et al. 2019: 64). Or the friendship that links him to Martin Nejedlý, executive director of the Czech branch of the Russian company Lukoil (Ereli 2017), in which he owns a 40\% share, whose money has been used to finance the election campaigns that Zeman himself has won (Špalková - Janda, 2018: 3). In fact, even when Nejedlý's company racked up multi-million-dollar debts - partly because of these extraordinary outlays - these debts were diligently cancelled by '...Lukoil headquarters in Moscow' (Špalková - Janda, 2018: 3). Such is the bond between the two that Nejedlý has become Zeman's chief adviser on international policy matters, accompanying him on official trips (on a diplomatic passport), ahead of many public office-holders linked to the Czech ministerial structure (Waisová 2020). Similarly, not only does Zeman feature so regularly in the Russian media that, like the TASS news agency, they present him as an ally to Putin or a counterweight to Washington (Špalková - Janda 2018: 2, Helmus et al. 2018), ${ }^{23}$ but also he himself is a vector of disinformation, repeating many of the false narratives published by alternative media and platform ${ }^{24}$ with possible links with the Kremlin (Janda Víchová, 2017; Krejčí 2017).

Though his friendships with Russian tycoons, dubious public practices with actors that have ties with Moscow, or his likely relationships with Russian organised crime do not point to any solid conclusions that Zeman's actions are politically motivated or allow us to accuse him (or excuse him) - using Soviet terminology -

23 Although the historical TASS cannot be compared with the popular and controversial Sputnik or RT, specifically devised to be a soft power tool to promote Russia's image internationally and erode the West's monopoly on news, it should be noted that this official news agency contributes to the country's information objectives. For a detailed account on this ecosystem, Herpen (2016).

24 For a broad account of the media and alternative platforms - which, in many cases, work to spread grey or black propaganda that will then be reproduced on social media as well as by media such as RT or Sputnik, thus making it difficult to attribute responsibility to the Kremlin - dedicated to such tasks, see Smoleňová (2015: 7-13) or Krejčí (2017). For an analysis of the ecosystem, see Helmus et al. (2018). 
of being an agent of Russian influence, ${ }^{25}$ nonetheless these actors, dynamics and practices that allow the Kremlin to plausibly deny its responsibility are still part of its traditional ecosystem of influence (Whitmore 2018; Galeotti 2017).

Therefore, when Zeman announced his willingness to hold a referendum for the Czech Republic's exit from the European Union and the Atlantic Alliance (Ereli 2017), many concluded that Zeman could be acting under Moscow's designs and that the Kremlin could be ultimately responsible for this movement. Because, as many sources - including Czech secret services (BIS 2016: 9) - had indicated prior to these statements, one of the objectives of Russian actions of influence in Eastern Europe is to dismantle the European security architecture built after the fall of the Iron Curtain (Polyakova et al. 2016: 4). As a result, several experts refer to Miloš Zeman as the Kremlin's 'Trojan Horse' in the Czech Republic (Špalková - Janda, 2018), using a metaphor that had already been used generically to refer to other European leaders who systematically support the Kremlin's activities on the old continent (Polyakova et al. 2016). In any case, either because Zeman is a devotee of Putin, because he has personal interests beyond political considerations, because he could be an agent of influence in the service of Russia or because he might have been the object of a campaign of reflexive control to influence his decisions, ${ }^{26}$ Zeman's actions clearly benefit the Kremlin directly or indirectly.

For his part, Prime Minister Andrej Babiš - dubbed the 'Czech Donald Trump' by the press - is also a former member of the Czechoslovak Communist Party of the Soviet era (in his case, from 1980 onwards), but he might also have worked as a secret agent during the Communist era (Tait, 2019). However, after the Velvet Revolution, Babiš became a business tycoon, founding Agrofert, a holding company that encompasses more than two hundred and fifty companies in sectors such as agriculture, chemicals, construction, energy and even the media. A traditional recipient of European subsidies, this business conglomerate recently suffered a major setback when the European Commission demanded the repayment of $£ 17.6 \mathrm{M}$ it had received unduly - as there was a conflict of interest, because Babiš continued to head up Agrofert - from Brussels between 2017 and 2019 (Transparency International 2019).

At the same time, Babiš - with personal assets of $\$ 4,600 \mathrm{M}$, making him one of the richest people in the country ${ }^{27}$ - faces additional charges for having

25 In general terms, an agent of influence uses their public position to secretly support Moscow, representing one of the traditional components of the aforementioned active measures (Bittman 1985).

26 Without citing this idea put forward by the USSR during the Cold War to try to influence - with limited success - the decision-making processes of allied governments, the Czech annual intelligence report for 2018 states that: 'The key Russian goal is to manipulate decision-making processes and the individuals responsible for the decision-making in order to force the counterparty to conduct activities to weaken itself' (BIS 2019: 6).

27 According to Forbes magazine in September 2020. Available at: https://www.forbes.com/profile/andrej-babis/\#77669a8021ee (28 September 2020). 
defrauded more than $€ 2 M$ in European funding (Janíček 2019). These accusations are not new, and indeed Babiš had already been charged with tax fraud as the Minister of Finance, forcing him to resign in May 2017 (Ereli 2017; Kopeček 2016). Not only is Babiš one of the richest people in the country, he also founded his own party - the Alliance of Dissatisfied Citizens (ANO). Purportedly created to fight corruption, this populist group, tailored to the aims of Babiš in 2011, is supported in the legislature by social democrats and communists, that is, by those who have traditionally been pro-Russian (Tait 2019).

Hence, it is plausible that the Kremlin would support these candidates. Indeed, during the 2018 presidential campaign, certain unusual events occurred, which Czech researchers use as proof of external interference (Krejčí Víchová - Janda, 2018). It was not the first time that misinformation entered the fray ${ }^{28}$. In the 2013 presidential election, candidate Karel Schwarzenberg, who fought against Zeman himself, was accused of having Nazi ancestors, and in the 2017 parliamentary elections the Social Democratic party was accused of trying to sell Czech lithium reserves to foreign corporations (Krejčí 2017). In this case, the rumour emerged from the alternative website Aeronet.cz - hosted in the Netherlands by an Indian client providing services to Russian companies (Weisburd 2015) and spreading pro-Kremlin narratives (Gazda - Šaur 2020: 186) - and was introduced into the country's mainstream media by Babiš, who used it as a weapon against the social democratic candidates. This was precisely one of the elements that explain ANO's victory in these elections (Krejčí 2017).

In the 2018 presidential election, polls predicted a very close result between Miloš Zeman and Jiří Drahoš, an independent pro-European and American-friendly candidate (Holzer et al. 2020). What broke out over those weeks was a fiercely fought dirty campaign of disinformation against Drahoš. The parliamentary elections of the previous year had already put this issue on the political agenda, and the government had opened the Centre against Terrorism and Hybrid Threats - dismissed by Zeman as pointless expenditure and a censorship body (Reuters 2017) - to combat disinformation. However, it returned to the fore when Drahoš was accused of being a former member of the Czechoslovak secret police during the Communist era, and it was argued that if he came to power he would allow immigration without limits. An accusation of paedophilia was even levelled against him (Krejčí - Víchová - Janda, 2018: 1). He was also accused of being a mason, of belonging to the Club of Rome, and discredited as a scientist and academic (he was president of the Academy of Sciences of the Czech Republic between 2009 and 2017) claiming that he appropriated the work

28 A comprehensive analysis of the 71 Czech and 6 foreign communication portals operating in the country and publishing fraudulent content can be found in Klingová (2018). It should be noted that the Czech site of the Russian news agency Sputnik (cz.sputniknews.com) is the most visited site in the country, while Aeronet.cz is the fourth and Novarepublica.cz is the eighth, with 806,000 and 564,200 visitors respectively. 
of his colleagues. He was even criminalised for being funded by the controversial George Soros. Although Soros has become a mainstay of the 'conspiranoia' narrative - as we are also seeing in our country - this issue was irrelevant to Czech public opinion, quickly denied by Hospodářské Noviny, and no candidate used this argument to attack Drahoš.

With regard to these propaganda activities, Aeronet.cz and Novarepublika.cz were particularly active sites, regularly included in European and allied reports on disinformation, for disseminating pro-Kremlin fake news and narratives ${ }^{29}$. However, unlike previous elections, there was propaganda paid for by private donors in newspapers (perhaps because, as in many countries, much of the adult population continues to get their news from traditional media), and social media such as Facebook played a major role in encouraging the users themselves to spread disinformation.

The issue that hurt Drahoš the most during the campaign was his portrayal to Czech public opinion as pro-immigration - a typical Russian misinformation issue given its ability to divide society, especially Eastern Europeans - when, in reality, his speech only condemned unrestricted 'economic immigration'. Although neither Novarepublika.cz nor the authorship of the disinformation campaign can be attributed (Syrovátka - Hroch, 2018), there are sources suggesting that some adverts carried in the traditional press were financed by Russian and Chinese funds (Krejčí - Víchová - Janda, 2018: 2).

One of the main characteristics of information and news activities carried out within a GZ is ambiguity. The lack of accredited sources and conclusive evidence prevent a firm conclusion from being reached - beyond the role played by Aeronet.cz which has circumstantial links with Russia - with regard to external interference or that this propaganda campaign would correspond to Zeman's own malpractice. If such interference occurred, it was limited, simple, and cheap because, unlike the US - and to some extent French - presidential elections that might suggest the Russian modus operandi in this regard, the popular news portal cz.sputniknews.com owned by the Russian news agency Sputnik - and the focus of misinformation - did not get fully involved in the propaganda campaign, and there are no recorded cases of hack \& leak or data access and filtering in forums, news aggregators, online platforms or mainstream media or their subsequent amplification through social media campaigns (Jeangéne et al. 2018).

There is also no record - although it was disseminated - of how adverts were bought on social media such as Twitter or Facebook, or of the organised use of trolls to interact with other online users and automated bots that amplify the

29 In this regard, see the reports published on the EU's External Action European Service portal EUvsDisinfo (https://euvsdisinfo.eu/) or the reports of the NATO - linked Centre of Excellence for Strategic Communication (https://www.stratcomcoe.org). 
impact of the former to expand the propaganda. In other words, this intense propaganda campaign against the opposition candidate cannot be attributed to Moscow (or Beijing), but their involvement cannot be ruled out either. This is precisely the ambiguity we were referring to when we defined grey zones.

Whether this information campaign was a decisive factor in the 2018 elections (Krejčí - Víchová - Janda 2018) or not (Syrovátka - Hroch 2018), or simply helped to sow the seeds of mistrust with regard to the opposition candidate, Zeman won the election by just 150,000 votes, keeping him in power as Russia-friendly leader...

\section{Other tools in the Czech grey zone}

The more or less well-founded suspicions of interference in electoral and political processes are becoming a classic trope when Russia is discussed (Jeangéne et al. 2018). But a GZ cannot be defined, identified or catalogued based solely on the use of this tool of influence. As noted previously, these situations underscore the debate between different narratives or accounts about the Czech Republic's historical relations with Russia. However, there are other tactics, techniques and procedures in place beyond political influence, propaganda manipulation or interference in electoral processes that can be included - together with the use of proxies with links with Moscow, cultural or social entities without any apparent relationship with Russia, blackmail, or direct and indirect collaborators (Bittman 1985) - within the traditional raft of Russian active measures. These include activities typically used in political warfare (Robinson et al. 2018).

This article focuses on economic pressure and military threat ${ }^{30}$, since, as pointed out in the theoretical framework, these are two of the mechanisms most present in GZ (Freier 2016; Baqués 2017; Chambers 2016; Jacob 2017). In fact, one could suspect that a combination of both measures is now taking place in the Czech Republic. This combination is, according to experts such as Jordán (2018: 132), the best option for a GZ, as well as the best indication that this type of scenario is ongoing.

Starting in 2008, coinciding with the signing of the agreement between Washington and Prague to install a component of the US missile defence shield on Czech soil, Russia not only used its traditional energy weapon - cutting off oil supplies from the Druzhba pipeline (Jirušek - Kuchyňková - Vlček 2020: 125) - but also launched an economic offensive to acquire critical Czech infrastructure. This was not the first time this tactic had been deployed. In 1994 and 2002 Russia tried unsuccessfully - perhaps because of the nearness of the Soviet past and the Czech Republic's determination to approach the West (Jirušek Kuchyňková - Vlček, 2020: 152) - to acquire Czech gas infrastructure. This

30 A comprehensive list of tools that can be used in the grey zone can be found in Jordán (2018). 
generated the typical dual interpretation: support for Czech income or a new form of servitude?

In particular, Russia tried to acquire the Czech airline (Czech Airlines - ČSA) and Prague airport. The Czech government wanted to privatise the company, and the main candidate to win the contract was Aeroflot, $51 \%$ owned by the Russian State. However, the contest was declared null and void in 2009 for no apparent reason. It is speculated that this was for security reasons, since this decision was reached after Aeroflot's offer was discussed in the lower house Security Commission (Kratochvíl - Kuchyňková, 2010: 203). ${ }^{31}$ Finally, in 2013 it was the South Korean company Korean Air that acquired 44\% of ČSA shares with the approval of the Czech government and the airline itself. Russia tried to do something similar with the public company Transgas, which imported energy - distributed in the country by the Russian company Gazprom after Zeman signed an agreement with Russia in 1998 (Posaner 2019: 251) - and which had been operated by the German RWE consortium since 2009. This attempt was also unsuccessful, for similar reasons, at least in the short term (Kratochvíl Kuchyňková 2010: 198). ${ }^{32}$

In addition to these movements, private Russian actors with possible links to the Kremlin also tried - sometimes successfully - to acquire technology firms, the media or Internet providers, feasibly to facilitate Russian intelligence and subversion (Bugajski 2004: 160) ${ }^{33}$, a possibility that would support the achievement of Russian influence objectives identified by the Czech secret services (BIS 2016: 9). In any case, Czech intelligence not only warns that certain countries implicitly referring to Russia or China - use their businesses to serve political, military or intelligence purposes (BIS 2019: 15), it also admits that many companies with Russian capital violate tax, regulatory or contractual rules, this being '...the relationship of capital with the "grey zone" of the legal system' (BIS 2016: 5).

However, beyond these activities, which at the time absorbed the attention of many media channels, what truly worries the Czech authorities is much more structural. Because, like its neighbours in Central and Eastern Europe, which are dependent on Russian hydrocarbons, the Czech Republic has suffered several supply interruptions since the 1990s, motivated by a wide range of circumstances, from domestic affairs to technical problems and disputes

31 The 2008 intelligence report also covered this privatisation but highlighted another issue: '....activities of potential bidders interested in the privatization [...] showed a dramatic increase. The interested parties were focusing mainly on developing contacts with relevant government officials and with the companies to be privatized, their objective being to use the contacts to acquire information or to build a better starting position compared to others' (BIS 2009: 4).

32 In 2015, RWE sold its oil and gas unit to Russian tycoon Mikhail Fridman, although this did not necessarily signify intent on the part of the Russian government.

33 In 2018, Czech secret services detected that the Federal Security Service (FSB) had attempted to create its own network - taking advantage of the infrastructures of these Internet providers - to carry out its cyberactivities in Europe (BIS 2019: 6-7). 
over transport charges (Jirušek - Vlček, 2015), which grew between 2007 and 2009, due to Russian pressures resulting from the signing of the US missile shield agreement, based on the supplies cut that revolved around Transneft (Morris et al. 2019: 68) 34 $^{34}$ This scenario coincides with the situation outlined by Chambers (2016: 20) in which such unlawful pressures do have political aims, not merely economic objectives ${ }^{35}$. The advantage of the GZ is that these measures can be taken in peacetime, that is, without apparent hostility, graduating them in the form of small - but escalating - doses (Jacobs, 2017: 80). In this way, it is very unlikely for the affected party to deduce a casus belli from those apparently isolated events and small doses. But, as it can be seen, the effects of these measures are serious on both internal and geopolitical scenarios.

Unlike some of its neighbours, the Czech Republic is not entirely dependent on Russian gas because of its strategy regarding energy diversification and the links forged with Western Europe in the 1990s (Jirušek - Kuchyňková Vlček. 2020: 121-22). Consequently, a significant part of its energy supply comes from other sources such as Norway, accounting for more than $20 \%$ of the total imported by the country (Kratochvíl - Kuchyňková 2010: 203-204). Although it is estimated that dependence on Russian gas is still between $40 \%$ and $50 \%$, in terms of oil this figure rises to $90 \%$, the bulk of which is transported through the Druzhba pipeline. Therefore, despite the efforts made so far, in one way or another, Czech energy insecurity is still patent, as the country's intelligence reminds us every year, clearly stating '...it is necessary to try to reduce its dependence on Russian sources' (BIS 2009: 4). In other words, Prague continues to face important limitations when it comes to rolling out policies that displease Moscow excessively. Perhaps for this reason, the radar referred to previously was not ultimately installed. This may indicate to what extent the Czech economic dependence is being exploited by Russia. The fact that some of the country's most important companies and infrastructures may fall into Russian (or Chinese) hands would increase the country's economic dependence. As said before, the use of economic means - in this case, mergers and acquisitions - to increase the political influence is an important characteristic of a GZ. In this sense, the successful pressure exerted by Russia would be a typical example of GZ 'public policy management' (Morris 2019: 68), despite the fact that some internal factors can prevent the GZ from displaying all the effects desired by its generator.

34 The company argued that there was no political intentionality, and that everything was due to technical problems, and that the fact it coincided with geopolitical issues was purely coincidental. But, interestingly, this took place parallel to official statements about the possibility of this radar system becoming a target for Russian missiles.

35 In other words, if the objectives were strictly economic, it is likely that Russia would not engage in these practices because of its short-term negative effects. In this way, the GZ theory is useful to deduce political or geopolitical intentions from apparently isolated and limited economic actions. 
Furthermore, Russia is a good trading partner to the Czech Republic, as one of the main importers of its products, mainly automobiles, chemical compounds and food (Kratochvíl - Kuchyňková 2010: 203). Whether because of this reason or due to his affinities with Moscow, Zeman was very critical of the sanctions imposed by the International Community on Russia following the annexation of Crimea. Although he argued that bilateral trade flows would suffer, that sanctions would harm Czech industry and Russian countermeasures would harm the country's farmers, the fact is that they have had little effect on the country's income (Coufalová - Žídek, 2020: 99-100). Therefore, did these criticisms respond to legitimate fears or were they due to other factors?

With regard to military threats, we must bear in mind that tensions in Russia were triggered in around the year 2007, owing to the possible deployment of the US missile shield. Indeed, local experts point out that an era of cold peace was ushered in, which has not completely disappeared even today. When this agreement was signed in the summer of 2008, Russian political and military authorities launched threats against the country and its military facilities, in particular against the radar deployment base and its associated systems. Starting with newly appointed President Dmitri Medvédev (2008-12), not given to public outbursts, but who declared that there would be 'reprisals' if this project were implemented; continuing with a surge in Russian secret services activity (BIS 2009: 5); and culminating in the statements made by General Nikolay Solovstov, the then head of the strategic missile force, who suggested that these facilities could become targets for their vectors, words that coincided with the testing of the new intercontinental missiles, the RS-12M Topol (SS-25 Sickle) (Kratochvíl - Kuchyňková 2010: 198).

The credibility of these threats was increased - perhaps unexpectedly, projecting the shadow of events from 1968 (BIS 2009: 5) - following Russia's military operation in Georgia shortly thereafter. Even though the missile shield crisis came to an end a decade ago, the events in Crimea and Donbass have not helped to ease the situation. However, although these fears remain present in Czech society, the country has been a member of NATO since 1999, so such action would certainly cause the invocation of Article V of the North Atlantic Treaty. Hence the importance of the GZ remaining under the threshold of armed conflict: it allows Russia to maintain its strategic initiative, to keep its escalation control and makes the invocation of Article V - and even Article IV of political consultations - virtually impossible.

Finally, although the ambiguity, anonymity and ubiquity of cyberspace make it a domain widely used to project power in grey zones, the cyberactivities that can be attributed to Russia against Czech interests do not warrant this label for the time being. Although the country experiences cyberattacks on its infrastructure or services every year, none of them has been attributed to Moscow. But Russia has been proven to be engaged in numerous cyberespionage tasks 
(though they affect data confidentiality and integrity, in fact they are not cyberattacks) and to have created a hub from which to launch cyberoperations against other European countries (BIS 2019: 8-9). Carried out by the Advanced Persistent Threat (APT-28) group of hackers linked to Russian military intelligence (Fireeye 2017) ${ }^{36}$, these campaigns target military personnel, public administration (especially the ministries of foreign affairs and defence), the political class or the industrial sector, to expose sensitive data. In addition to being used for political, scientific, military or industrial purposes, they have also been used to slander, disinform or blackmail individuals and collectives (BIS 2017: 27), a standard Soviet active measure.

Likewise, although Russian cybercrime - often used to support the Kremlin's objectives (Galeotti 2017) - operates widely in the country, it seems to focus on lucrative activities. This would indicate that, while Russia is widely using the information environment to project its influence over the Czech Republic, its activities in cyberspace focus on intelligence (in some cases proving its authorship) and support for active measures. However, it is likely that, when Moscow deems it necessary, it will be able to use its cybernetic means to launch large-scale attacks on critical infrastructure and services, whilst plausibly denying its authorship.

\section{Conclusions: Is a Russian grey zone being constructed in the Czech Republic?}

When we refer to the possibility that a grey zone is being created, we cannot be satisfied simply by the isolated appearance of some of its ingredients. The possibility of creating a false positive means this would not be enough to verify the creation of a GZ. However, the combination of these ingredients would confirm this hypothesis. In that respect, what is happening in the Czech Republic does not appear to go unnoticed among analysts. The most relevant is the spatial and temporal combination (in this particular case, the last decades in the Czech Republic) of several of the best-known tools for a GZ. It is not only a matter of having 'Trojan horses' in the Czech Republic, but of having their discourse (the narrative promoted by those leaders) combined with economic and military pressures generated by the great power interested in creating that GZ.

In 2017 - nine years after Prague warned that Russia had taken up active measures once more to influence the country - a report commissioned by the European Parliament admitted the existence of irregular activities on Czech territory encouraged from Russian soil. It refers to cyber threats, links with political parties and leaders, and powerful propaganda generated mainly through

36 Paradoxically, Czech sources hardly refer to APT-29, which is linked to the FSB and it is the other relevant actor in the Russian cyberactivities. 
Russian media broadcasting in Czech (Façon 2017). Although the activities of Sputnik, which garners a huge audience in the country and which acts as the Kremlin's conveyor belt, are mentioned, perhaps more important are the vast amalgam of online media that cover up their origin, build grey propaganda, and replicate fake news. The report also mentions the existence of organisations that, like the Institute of Slavic Strategic Studies, promote and participate in Pan-Slavic congresses, networking in favour of Moscow with a view to strengthening the growing network of NGOs aligned with its aims (Morris 2019: 67). The narratives that have been spread include the supposed existence of a 'nuclear cloud' from France, the imminent - but hypothetical - merger of Czech and German military units, and all manner of messages seeking to discredit the European Union and the Atlantic Alliance. Therefore, section (e) described in the theoretical framework is more than fulfilled.

However, it seems paradoxical that such reports, which discover with astonishment the hybrid threats coming from Moscow, seem to bypass the traditional recipes of political warfare and, above all, the long history of active measures to influence, subvert and destabilise societies. As the Czech secret services first warned in 2008, this technique seems clearly exposed, and not only for the Czech Republic: recruitment of collaborators, support for civil organisations (section $\mathrm{f}$ of the theoretical framework), parties and leaders acting as fifth-columnists, aggressive intelligence gathering, dissemination of narratives and support for activities that can divide and radicalise society, economic blackmail (especially with natural gas and oil, which fits in with section $g$ of the theoretical framework) and even military threat (section h). What is new, however, in cases such as that of the Czech Republic, is that Russia seems willing to generate such pressure in pursuit of its national interests. Why? Given Zeman-Babiš's agenda - exploiting anti-European feeling in society with siren songs in the form of Czexit style referendums - it seems that the answer is clearly contained in a simple syllogism: weaken the European Union and the Atlantic Alliance to increase influence in the country as if it were a zero-sum game (which coincides with Russian ambitions to control the Czech agenda by influencing its choice of governors, explained in section $b$ of the theoretical framework). For a decadent and insecure power such as Russia, Allied and European expansions are seen as a (false) offensive spiral initiated by the West, against which, given the lack of military response capacity, it has opted for soft measures, which do not cause an outbreak of hostilities (section $c$ of the theoretical framework) even though the price to be paid is that the engineered influence is achieved very slowly (section a of the theoretical framework).

However, each GZ scenario has its own characteristics. Some make the development of a GZ more complicated, or more laborious, or more time-consuming, while, in other cases, they can facilitate its development. In the case of the Czech Republic, there certainly are such facilities. Indeed, many political scientists 
argue that one of the country's problems lies in the sharp contrast that has been maintained between government and opposition positions, whenever relations with Russia, the United States and the European Union are discussed. Some sources already flagged more than a decade ago that Russia would try to take advantage of this, and time has proved them right. The moral of the tale is clear: political fragmentation on State matters has been excellently exploited by Russia, and perhaps also by China, which seems to be using similar tactics to increase its influence in the country (BIS 2018: 9).

Whether or not the creation of a GZ is a guarantee of success is another matter entirely, quite simply because it is not. The effects of such events are not automatic, but they are usually noticeable in the short and medium term. In the case of the Czech Republic, we know that a significant part of the population remains pro-Russian. We just have to look at the MPs that have joined the ranks of the Communist Party and the Social Democrat Party, the audience garnered by Sputnik, or the results obtained by Milos Zeman in the last presidential election. However, other sectors of the population, of the administration, and the local elites have, for obvious reasons, become more suspicious of the Kremlin.

Pressure stemming from Russia may be having a boomerang effect. Growing anti-Russian feeling may have less to do with the Prague Spring and much more to do with coverage of its campaigns of influence. But the Czech authorities of the time reacted against Russia, claiming that Moscow still considered the Czech Republic to be a Russian satellite (Kratochvíl - Kuchyňková, 2010: 199). As a result, in June 2019, some 250,000 people took to the streets demanding the resignation of the Prime Minister, reeling off slogans that denounced him as a threat to democracy. These demonstrations took place in Letna Park, and protesters repeated Havel's old slogans (such as 'truth and love' will conquer all). It is important to note, therefore, that a GZ is not demonstrated by its results, but by its intentions/purposes and tools/means.

Our analysis could end here, having tested hypotheses through a case study. However, as we have announced in the methodological part of the article, we do not settle for this. Case studies can also be used for improving existing theories. Along these lines, authors such as Kapusta (2015: 9) leave the door open for a State to develop GZ activities, but without developing a 'real' GZ with all its attributes and effects. What would be the raison d'être of this approach? That the revisionist State using this strategy might seek, above all, to compare the level of alarm (and response) that these activities generate among the status quo ante powers. We understand that the logic inherent in the 'probing behavior' theory advocated by Grygiel and Mitchell (2017) should be interpreted as the next step in the interpretative line barely hinted at by Kapusta.

In this way, experiences such as those of the Czech Republic could also be interpreted as a partial, incomplete or in fieri GZ. Or, if preferred, as a limited grey zone (LGZ). Because, notwithstanding some major successes, the measures 
adopted appear to be aimed at matching the degree of alarm and response - but also, in the opposite sense, the doubts and shortcomings of the lack of resolve of the defenders of the status quo. All this, of course, without detracting from the societal erosion resulting from the deployment of these GZ activities. This thesis could, moreover, constitute an appropriate development of the theories from Kapusta, Grygiel and Mitchell.

\section{References}

Baqués, Josep (2017): Hacia una definición del concepto Gray Zone (GZ), Documento de Investigación del IEEE 2/2017: available at http://www.ieee.es/Galerias/fichero/docs_investig/2017/ DIEEEINV02-2017_Concepto_GaryZone_JosepBaques.pdf (27 August 2020).

Benyumov, Konstantin (2018): 'How Soviet invasion changed the Czechs forever', Meduza (21 August): available at https://meduza.io/en/feature/2018/08/24/before-1968-we-had-nothing-against-russia-or-the-soviet-union (29 August 2020).

Berzins, Janis (2015): Russian New Generation Warfare is not Hybrid Warfare, in Pabriks, Artis Kudors, Andis, eds., The War in Ukraine: lessons for Europe, 40-52, Riga: University of Latvia Press.

Bittman, Ladislav (1985): The KGB and Soviet disinformation: an insider's view, New York: Pergamon.

Bradshaw, Samantha - Howard, Philip (2018): Challenging truth and trust: a global inventory of organized social media manipulation. Oxford: Oxford Internet Institute.

Brands, Hal (2016): 'Paradoxes of the Gray Zone'. Foreign Policy Research Institute (5 February): available at https://www.fpri.org/article/2016/02/paradoxes-gray-zone/ (30 August 2020).

Bugajski, Janusz (2004): Cold Peace: Russia's New Imperialism, Praeger.

Byman, Daniel (2020): 'Is deterrence restored with Iran?'. The Brookings Institution (16 January): available at https://www.brookings.edu/blog/order-from-chaos/2020/01/16/is-deterrence-restored-with-iran/ (28 August 2020).

Chambers, John (2016): Countering Gray-Zone Hybrid Threats, Modern War Institute.

Colom, Guillem (2019): La amenaza híbrida: mitos, leyendas y realidades, Documento de Opinión del IEEE 24/2019: available at http://www.ieee.es/Galerias/fichero/docs_opinion/2019/ DIEEEO24_2019GUICOL-hibrida.pdf (25 August 2020).

Cooperman, Alan, dir. (2017): Religious Belief and National Belonging in Central and Eastern Europe, Washington DC: Pew Research Center.

Coufalová, Lucie - Žídek, Libor (2020): The Big Partner with a Small Turnover: Czech-Russian Economic Relations and Their Dynamics, in Holzer, Jan - Mareš, Miroslav, eds., Czech Security Dilemma. Russia as a Friend or Enemy?, 91-115, London: Palgrave Macmillan. 
CTK (2011). 'Former Czech PM sued over statements on Islam', Prague Daily Monitor (8 July): available at: http://praguemonitor.com/2011/07/08/former-czech-pm-sued-over-statements-islam (11 September 2020).

Daniel, Jan - Eberle, Jakub (2018): Hybrid Warriors: Transforming Czech Security through the ‘Russian Hybrid Warfare' Assemblage. Sociologický časopis 54 (6): 907-932.

Dodge, Michaela (2020): U.S.-Czech ballistic missile defense cooperation: Lessons learned and way forward for others. Comparative Strategy 39 (3): 288-298.

Echevarria, Atulio (2016). Operating in the Gray Zone: An alternative Paradigm for US Military Strategy. Carlisle Barracks: U.S. Army War College.

Ereli, Adam (2017): 'Elephants in the room. Is the Czech Republic Falling Under Putin's Shadow?' Foreign Policy (10 October): available at: https://foreignpolicy.com/2017/10/10/is-the-czech-republic-falling-under-putins-shadow/ (6 September 2020).

Facon, Isabelle (2017): Russia's national security strategy and military doctrine and their implications for the EU. Brussels: Directorate-General for External Policies, European Parliament.

FireEye (2017): APT28: at the center of the storm. Russia strategically evolves its cyber-operations. Milpitas: FireEye.

Freier, Nathan (2016): Outplayed: Regaining Strategic Initiative in the Gray Zone. Carlisle Barracks: U.S. Army Strategic Studies Institute.

Galeotti, Mark (2017): Crimintern: How the Kremlin uses Russia's criminal networks in Europe. London: European Council on Foreign Relations.

Galeotti, Mark (2016): 'Hybrid, ambiguous, and non-linear? How new is Russia's new way of war?' Small Wars \& Insurgencies 27 (2): 282-301.

Gareev, Makhmut (1998): If War Comes Tomorrow?: The Contours of Future Armed Conflict. London: Frank Cass.

Gazda Jiří - Šaur, Josef (2020): Slavonic Brothers? Current Language, Literature and Cultural Interaction Between Russia and the Czech Republic in Light of the Security Issue, in Holzer, Jan - Mareš, Miroslav, eds., Czech Security Dilemma. Russia as a Friend or Enemy?, 177-196, London: Palgrave Macmillan.

Goldman, Emily (2006): Power in Uncertain Times. Strategy in the Fog of Peace. Stanford: Stanford University Press.

Grygiel, Jakub - Wess, Mitchell (2017): The Unquiet Frontier. Rising Rivals, Vulnerable Allies, and the Crisis of American Power. Princeton: Princeton University Press.

Haddick, Robert (2012): 'Salami Slicing in the South China Sea: China's slow, patient approach to dominating Asia'. Foreign Policy (3 August): available at https://foreignpolicy.com/2012/08/03/ salami-slicing-in-the-south-china-sea/ (29 August 2020).

Hanley, Seán - Vachudova, Milada (2018): Understanding the illiberal turn: democratic backsliding in the Czech Republic. East European Politics, 34 (3): 276-296.

Helmus, Todd et al. (2018): Russian social media influence. Understanding Russian propaganda in Eastern Europe. Santa Monica: RAND Corporation. 
Herpen, Marcel (2016): Putin's Propaganda Machine: Soft Power and Russian Foreign Policy. Lanham: Rowman \& Littlefield.

Hoffman, Frank (2015): The Contemporary Spectrum of Conflict: Protracted, Gray Zone, Ambiguous, and Hybrid Modes of Warfare, in Wood, Dakota, ed., 2016 Index of U.S. Military Strength: Assessing America's Ability to Provide for the Common Defense, 25-36, Washington DC: Davis Institute for National Security and Foreign Policy.

Hoffman, Frank (2012): Future Hybrid Threats: An Update. Washington DC: Center for Strategic Rersearch.

Hoffman, Frank (2007): Conflict in the $2^{15 t}$ Century: the rise of hybrid wars. Arlington: Potomac Institute for Policy Studies.

Holzer, Jan - Jirušek, Martin - Kuchyňková, Petra (2020): Russia as Viewed by the Main Czech Political Actors, in Holzer, Jan - Mareš, Miroslav, eds., Czech Security Dilemma. Russia as a Friend or Enemy?, 55-89, London: Palgrave Macmillan.

Jacob, Frank (2017). Asymetric Wars and US strategy, in Romaniuk, Scott y Grice, Francis, eds, The Future of US Warfare, 71-85, London \& New York: Routledge.

Janda, Jakub - Víchová, Veronika (2017): The Kremlin's hostile influence in the Czech Republic: The state of play. Warsaw: Warsaw Institute.

Janíček, Karel (2019): 'Czech leader to face fraud charges after decision overturned', The Washington Post (4 December): available at: https://www.washingtonpost.com/world/europe/ czech-leader-to-face-fraud-charges-after-decision-overturned/2019/12/04/6f4fddd2-169d11ea-80d6-d0ca7007273f_story.html (5 September 2020).

Jirušek, Martin - Vlček, Tomáš, eds. (2015): Energy Security in Central and Eastern Europe and the Operations of Russian State-Owned Energy Enterprises. Brno: Masaryk University.

Jirušek, Martin - Kuchyňková, Petra - Vlček, Tomáš (2020): Business as Usual or Geopolitical Games? Russian Activities in Energy Sector of the Czech Republic, in Holzer, Jan - Mareš, Miroslav, eds., Czech Security Dilemma. Russia as a Friend or Enemy?, 117-149, London: Palgrave Macmillan.

Jordán, Javier (2018): El conflicto internacional en la zona gris: una propuesta teórica desde la perspectiva del realismo ofensivo. Revista Española de Ciencia Política, 48: 129-151.

Karber, Phillip - Thibeault, Joshua (2016): 'Russia's New Generation Warfare', Association of the United States Army (20 May): available at https://www.ausa.org/articles/ russia\%E2\%80\%99 s-new-generation-warfare (10 November 2020).

Kapusta, Philip (2015): The Gray Zone. Special Warfare, 28 (4): 18-25.

Klingová. Katarína (2018): What Do We Know About Disinformation Websites in the Czech Republic and Slovakia? Bratislava: Globsec.

Kopeček, Lubomír (2016): I am Paying, So I Decide. Czech ANO Party as an Extreme Form of a Business-Firm Party. East European Politics and Societies: and Cultures, 30 (4): 5-38.

Koven, Barnett (2016): The Conflict of Donbass between Gray and Black: The Importance of Perspective. Baltimore: National Consortium for the Study of Terrorism. 
Kratochvíl, Petr - Kuchyňková, Petra (2010): Russia in the Czech Foreign Policy, in Kořan, Michal et al., eds., Czech Foreign Policy in 2007-2009. Analysis, 196-212, Prague: Ústav mezinárodních vztahů.

Kratochvíl, Petr (2004): Political Relations between Russia and the Czech Republic: or there and back again?, Economic and Political Relations After the EU Enlargement, Budapest: ICEG EC Conference.

Krejčí, Markéta (2017): The ins and outs of the Czech disinformation community. New Eastern Europe (8 November): available at https://neweasterneurope.eu/2017/11/08/ins-outs-czech-disinformation-community/ (16 August 2020).

Krejčí, Markéta - Víchová, Veronika - Janda, Jakub (2018): The role of the Kremlin's influence and disinformation in the Czech presidential elections, European Values. Available at https:// www.kremlinwatch.eu/userfiles/the-role-of-the-kremlin-s-influence-and-disinformation-in-the-czech-presidential-elections_15263778517686.pdf (10 September 2020).

Mareš, Miroslav - Holzer, Jan - Šmíd, Tomáš (2020): The Hybrid Campaign Concept and Contemporary Czech-Russian Relations, in Holzer, Jan - Mareš, Miroslav, eds., Czech Security Dilemma. Russia as a Friend or Enemy?, 15-33, London: Palgrave Macmillan.

Matisek, Jahara (2017). Shades of Gray Deterrence: Issues of Fighting in the Gray Zone. Journal of Strategic Security 10 (3): 1-26.

Mazarr, Michael (2015): Mastering the Gray Zone: Understanding a Changing Era of Conflict. Carlisle Barracks: U.S. Army War College.

Merriam, Sharan (1998): Qualitative research and case study applications in education. San Francisco: Jossey-Bass.

Morris, Lyle et al. (2019): Gaining Competitive Advantage in the Gray Zone. Response Options for Coercive Aggression Below the Threshold of Major War. Santa Monica: RAND Corporation.

Paszewski, Tomasz (2013): U.S. Missile Defense Plans: Central and Eastern Europe. Revue d'études comparatives Est-Ouest, 44: 35-60.

Polyakova, Alina et al. (2016): The Kremlin's Trojan horses. Washington DC: Atlantic Council of the United States.

Polyakova, Alina - Boyer, Spencer (2018): The future of political warfare: Russia, the West, and the coming age of digital competition. Washington DC: Brookings Institution.

Posaner, Joshua (2019): Held Captive by Gas: The Price of Politics in Gazprom's Long-Term Contracts with Central European Buyers 2009 to 2014. New York: Springer.

Reuters (2017): 'Czech ,hybrid threats' center under fire from country's own president' (4 January): available at: https://www.reuters.com/article/us-czech-security-hybrid-idUSKBN14O227 (25 September 2020).

Ridder, Hans-Gerd (2017): The theory contribution of case study research designs. Business Research, 10: 281-305.

Robinson, Linda et al. (2018): Modern Political Warfare. Current Practices and Possible Responses. Santa Mónica: RAND Corporation. 
Security Information Service [BIS] (2019): Annual Report of the Security Information Service for 2018. Prague: Intelligence Service of the Czech Republic.

Security Information Service [BIS] (2018): Annual Report of the Security Information Service for 2017. Prague: Intelligence Service of the Czech Republic.

Security Information Service [BIS] (2016): Annual Report of the Security Information Service for 2015. Prague: Intelligence Service of the Czech Republic.

Security Information Service [BIS] (2011): Annual Report of the Security Information Service for 2010. Prague: Intelligence Service of the Czech Republic.

Security Information Service [BIS] (2009): Annual Report of the Security Information Service for 2008. Prague: Intelligence Service of the Czech Republic.

Security Information Service [BIS] (2004): Annual Report of the Security Information Service for 2003. Prague: Intelligence Service of the Czech Republic.

Schadlow, Nadia (2014): 'Peace and War: the Space between', War in the Rocks (18 August): available at https://warontherocks.com/2014/08/peace-and-war-the-space-between/ (26 August 2020).

Smoleňová, Ivana (2015): The Pro-Russian Disinformation Campaign in the Czech Republic and Slovakia. Prague: Prague Security Studies Institute.

Špalková, Veronika - Janda, Jakub (2018): Activities of Czech President Miloš Zeman as the Kremlin's Trojan Horse. European Values: available at https://www.europeanvalues.net/wp-content/ uploads/2018/01/Activities-of-Czech-President-Milo\%C5\%A1-Zeman.pdf (10 August 2020).

Stake, Robert (1994): Case Studies, in Normal Denzin - Yvonna Lincoln, eds., Handbook of Qualitative Research, 236-247, London: Sage.

Stoker, Donald - Whiteside, Craig (2020): Blurred Lines: Gray-Zone Conflict and Hybrid War-Two Failures of American Strategic Thinking. Naval War College Review 73 (1): 1-37.

Syrovátka, Jonáš - Hroch, Jaroslav (2018): Čské volby v ére desinformací. Presidential Election 2018. Prague: Prague Security Studies Institute.

Tait, Robert (2019): 'Czech Republic: protesters demand Prime Minister's resignation', The Guardian (23 June): available at https://www.theguardian.com/world/2019/jun/23/czech-republic-protesters-demand-prime-ministers-resignation (15 August 2020).

Thomas, Timothy (2016): 'The Evolution of Russian Military Thought: Integrating Hybrid, New-Generation, and New-Type Thinking'. The Journal of Slavic Military Studies 29 (4): 554-575.

Transparency International (2019): European Commission audit report finds Czech Prime Minister has a conflict of interest, Transparency International (4 December): available at: https://www.transparency.org/news/pressrelease/european_commission_audit_report_ finds_czech_prime_minister_has_conflict_of (11 August 2020).

Trenin, Dimitri (2011): Post-Imperium: A Eurasian History. Washington DC: Carnegie Endowment for International Peace.

Votel, Joseph et al. (2016): Unconventional Warfare in the Gray Zone. Joint Forces Quarterly, 80 (1): 101-109. 
Waisová, Šárka (2020): Central Europe in the new Millennium: The new Great Game? US, Russian and Chinese interests and activities in Czechia, Hungary, Poland and Slovakia. Revista UNISCI, 54 (October): 29-48.

Walker, Shaun (2018): 'Russian presence divides Czechs 50 years after Prague Spring'. The Guardian (20 August): available at: https://www.theguardian.com/world/2018/aug/20/russian-presence-divides-czechs-50-years-after-prague-spring (13 September 2020).

Weisburg, Andrew (2015): 'aeronet.cz: Kremlin Op Targeting Czechs and Slovaks', Kremlin Trolls (4 July): available at http://kremlintrolls.com/t/20150704-aeronet-cz.html (17 August 2020).

Wesolowsky, Tony (2003): Czech Republic. From Russia, with love. Bulletin of Atomic Scientists, 59 (1): 15-17.

Whitmore, Brian (2018): Putin's Dark Ecosystem. Washington DC: Center for European Political Analysis.

Yin, Robert (2014): Case study research. Design and methods. London: Sage.

Josep Baqués-Quesada is a professor of geopolitics and international relations at the Universidad of Barcelona, Spain and at the "General Gutiérrez-Mellado Institute", Madrid. He holds a PhD in political science, and a master in international relations. He is also co-director of the master's degree in prevention of radicalization, editor of the Revista de Estudios en Seguridad Internacional (RESI) and a regular contributor to the Spanish Institute for Strategic Studies and to the Training and Doctrine Command of the Spanish Army. E-mail: jbaquesq@ub.edu.

Guillem Colom-Piella is a professor of political science at the Universidad Pablo de Olavide, Spain and Associate Researcher at the Universidad Autónoma de Chile, Chile. Prior to taking up his university roles, he worked in the Armed Forces Transformation Unit in the Spanish Defence Staff. He holds a PhD in international security and a master in international relations.E-mail: gcolpie@upo.es. 